\title{
BALANCING IN- AND OFF-STREAM USES OF WATER IN THE HAWAIIAN ISLANDS
}

\author{
STEVEN SPENGLER ${ }^{1}$, MARVIN HESKETT ${ }^{1}$, DEAN UYENO $^{2}$ \& AYRON STRUACH ${ }^{2}$ \\ ${ }^{1}$ Element Environmental, Hawai‘i, USA \\ ${ }^{2}$ State of Hawai‘i Commission on Water Resource Management, Hawai‘i, USA
}

\begin{abstract}
The island of Kaua' $i$ is the oldest of the main Hawaiian Islands and has roughly 70,000 inhabitants. Sugar plantations historically dominated the island's economy but have been largely supplanted by tourism in recent years. The surface water resources in the Waimea River watershed on Kaua'i were diverted at the beginning of the twentieth century by former sugar plantations into roughly 77 kilometers of transmission ditches, tunnels, flumes, and siphons of the Kekaha Ditch Irrigation System (KEDIS) and the Kōke'e Ditch Irrigation System (KODIS). These ditch systems were constructed to transport water to the arid, fertile lands of the Mānā Plain that required irrigation water to grow sugarcane. A 2013 petition by community groups to the State of Hawai' $\mathrm{i}$ Commission on Water Resource Management (CWRM) demanded that stream flow be restored and that interim instream flow standards for the Waimea River and its headwater and tributaries be established. The current amount of water diverted into the two ditch systems exceeds present-day agricultural needs, which are dominated by corn seed crops. However, the island's electric utility has developed plans to use the water stored in the existing high elevation reservoirs on KODIS to produce electricity using pumped hydropower storage technology. Pumped hydropower would allow the utility to "store" excess energy produced by the island's rapidly expanding utility-scale photovoltaic array systems with the ultimate goal of producing all of the island's electricity using renewable resources. The physical condition and volume of water currently diverted by both ditch systems was evaluated and measured by Element Environmental (E2). CWRM is using the information collected to establish water diversion guidelines that strike a balance between off-stream uses (agriculture and hydroelectric power production) and instream uses of this water, including maintenance and restoration of stream and riparian habitat and ecosystems as well as protection of traditional and customary Hawaiian rights.
\end{abstract}

Keywords: surface water resource, Hawaiian rights, Kokee Ditch, Kekaha Ditch, Kauai, Hawaii.

\section{INTRODUCTION}

The surface water resources in the Waimea River watershed on Kaua'i were diverted at the beginning of the twentieth century by the Kekaha Sugar Company (KSC) into kilometers of transmission ditches, tunnels, flumes, and siphons of the Kekaha Ditch Irrigation System (KEDIS) and the Kōke'e Ditch Irrigation System (KODIS). These ditch systems were constructed to transport water to the arid ( $\sim 50 \mathrm{~cm}$ annual rainfall), fertile lands of the Mānā Plain that required irrigation water to grow sugarcane. Since the demise of large-scale sugarcane production in the late 1990s in Hawai'i, the conditions have been set for a reevaluation of the balance between historic off-stream uses (agriculture and hydroelectric power production) and instream uses of this water, including maintenance and restoration of stream and riparian habitat and ecosystems as well as protection of traditional and customary Hawaiian rights.

\section{SUMMARY OF EARTHJUSTICE COMPLAINT}

On July 24, 2013, two community groups, Po'ai Wai Ola and the West Kaua'i Watershed Alliance, submitted a complaint and petition for a declaratory order through their attorneys (Earthjustice) against the waste of water diverted from the Waimea River watershed by the state Agribusiness Development Corporation (ADC) and its land manager, the tenant 
association, Kekaha Agriculture Association (KAA). The complaint alleged that despite the dramatic decline in cultivation and actual water demands following the closure of the KSC, the large-scale diversion of water into the KEDIS and KODIS continued in amounts comparable to volumes diverted during operation of the former sugarcane plantation. The on plaintiffs alleged that the on-going diversion is detrimental to the aquatic habitat in the various streams within the Waimea watershed. This legal action included a petition requesting that the State of Hawai'i Commission on Water Resource Management (CWRM, the Commission) restore stream flow and amend interim instream flow standards (IIFSs) for the Waimea River and its headwater and tributaries. The Plaintiffs requested additional monitoring and reporting on the two ditch systems, including determination of average daily water usage by the various end users, breakdowns of acreages and crops cultivated, reservoir volumes, and determination of losses within the ditch systems.

The Commission executed a Contract for Professional Services with E2 to collect information that would assist the Commission in the matter of the Earthjustice complaint. The investigation and fact gathering work conducted by E2 involved meeting with the parties pertinent to the complaint, conducting an inventory and assessment of the existing infrastructure of KEDIS and KODIS, monitoring the current flow within the two ditch systems, and preparing a comprehensive report describing the findings from these assessments and monitoring to the Commission.

\section{DESCRIPTION OF WAIMEA WATERSHED}

The Waimea River watershed lies on the leeward side of the island of Kaua' $i$ in the Hawaiian Islands. The watershed covers an area of about 222.5 square kilometers, and reaches a maximum elevation of 1,598 meters at Mount Wai'ale'ale. Mount Wai'ale'ale is one of the wettest places on the earth with around 11 meters of annual rainfall, while the Mānā Plain, located 23 kilometers to the west receives less than 0.5 meters of annual rainfall. The portion of the watershed evaluated during this study covers an area of around 150.2 square kilometers, which excludes the Makaweli River portion of the basin to the east. In Hawaiian, Waimea means "reddish water", a possible reference to the erosion of the red soil exposed in the sidewalls surrounding the river that produced this spectacular canyon.

KEDIS and KODIS receive water from the various streams and tributaries located within the Waimea River watershed located on the southwest side of the island of Kaua'i. The watershed contains 38 streams totaling 444.8 kilometers in length, as well as eight waterfalls (Parham et al. [1]). The northern part of the watershed consists of an open rolling but swampy area called the Alaka'i Swamp, which serves to some degree as a natural reservoir, regulating the flow of runoff to the various streams that drain this plateau. This plateau is underlain by the thick basaltic lavas of the Olokele Formation. The western edge of the watershed contains Waimea Canyon, a spectacular wilderness of 600 to 900 meter deep gorges, rugged crags,

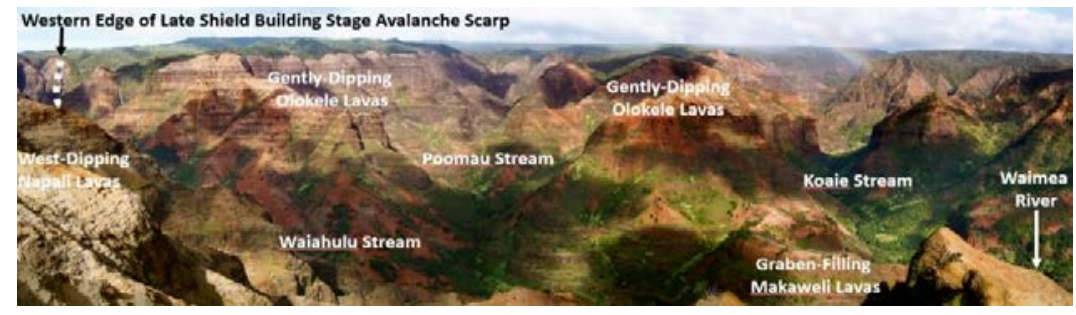

Figure 1: Panoramic photograph of streams and geologic formations exposed in the Upper Waimea Watershed. 
and labyrinthine canyons through which the Waimea River and its tributaries flow. The Waimea River meanders in a generally southerly direction in a roughly 1.6 kilometer wide canyon collecting surface flows from various northern headwaters and tributaries that drain down from the Alaka'i Swamp, and from lower eastern tributaries, before joining the Makaweli River and flowing into Waimea Bay. This eastern portion of the Waimea River watershed that flows to the Makaweli River, including its main tributary the Olokele, was not a part of the current study.

The 17.9 kilometer main section of the Waimea River starts just below the confluence of the Waiahulu and Koaie Streams. About 1.5 kilometers further up the canyon, Po'omau Stream (a perennial stream) joins the Waiahulu Stream (an ephemeral stream under natural conditions above this point). The Po'omau and Waiahulu Streams flow through the inland floor of the Waimea Canyon. The chief tributaries that flow into Waimea Canyon and enter these two streams (from west to east) include Halemanu, Kōke'e, Kaua'ikainanā, Kawaikōī, Waikoali, and Mōhihi Streams. Koaie, Wai'alae, and Mokihana Streams enter the Waimea River further to the south and drain the southeastern, wetter portion of the plateau. These tributary streams generally originate in the bogs of the Alaka'i Swamp between 1,100 to 1,500 meter elevation. KEDIS extends into the Mānā Plain, a 14.5 kilometer long, 3.2 kilometer wide relatively flat area containing sand dunes along the shoreline and agricultural fields throughout much of the plain's gently sloping interior.

\section{DITCH SYSTEM USE, HISTORY AND OPERATION}

The early sugarcane growers in western Kaua' $i$ in the 1870s lacked an abundant and reliable water supply, relying on natural springs, intermittent streams, and groundwater pumped from a series of wells drilled throughout the Mānā Plain. As the acreage of land growing sugarcane increased, these sources of water proved inadequate. Between 1903 and 1926, engineers with KSC designed three separate ditch systems, KEDIS, KODIS and Waimea, that could divert large quantities of surface water from the perennial streams within the Waimea River watershed at intake structures, into kilometers-long transmission ditches and tunnels that conveyed the captured water to the arid, but fertile, leeward Mānā Plain. The intake structures typically consisted of a dam constructed across the streambed, an inlet channel, control gates, trash screen, and a connecting tunnel or ditch into the main transmission structure (usually another tunnel or ditch). Teams of Japanese and Chinese immigrant tunnel workers constructed these largely unlined ditch systems by blasting tunnels and excavating conveyance ditches through hard rock and alluvium. Two hydropower plants were built on KEDIS; a 1,200 kilowatt $(\mathrm{kW})$ capacity plant known as the Mauka Plant located adjacent to Waimea River and a 500 kW capacity plant in Waiawa Valley above the Mānā Plain. In 1923, the company undertook major repairs of KEDIS, expanding its capacity to 50 million gallons per day (mgd) (1 gallon=3.785 liters) and its average flow to 35 mgd along with 95 million gallons of storage capacity in a series of reservoirs constructed in the alluvial slopes just above the Mānā Plain.

At the same time, KSC started construction on KODIS, in order to deliver and store water to allow irrigation of 810 additional hectares of sugarcane in the highland region above the Mānā Plain. KODIS was designed to capture as much of the freshets as possible that develop in the tributaries in the headwaters of the Waimea River after heavy rainfall events. The upper section of this ditch system runs near the cliff line along the southern edge of the upland plateau near Kōke'e and consists of a system of small dams that intercept flow from Waikoali, Kawaikōī, Kaua'ikananā, and Kōke'e Streams at elevations between 1,005 and 1,040 meter above sea level. The diverted stream water is then conveyed through 34 kilometers of ditches, 48 tunnels, flumes, and reservoirs with an average elevation drop of one meter per 1,000 
linear meter traversed. Pu'u Lua Reservoir, the major storage facility for KODIS, was finished in 1927, with a capacity of 262 million gallons. This earthen dam reservoir was situated at an elevation of 995 meters above sea level. The 36-million gallon capacity Kitano and the 88-million gallon capacity $\mathrm{Pu}^{\text {' }} \mathrm{u}$ 'Ōpae Reservoirs were constructed at the terminus of the 34 kilometer long KODIS. The water stored in these three upland storage reservoirs was historically used to irrigate highland sugarcane fields located east of Kōke'e Road and below $\mathrm{Pu}$ 'u 'Ōpae Reservoir during the plantation era.

Additional land in the Mānā Plain was reclaimed in the 1920s by KSC for sugarcane cultivation by constructing an intricate series of drainage canals that drained the natural swamps present within the plain. By the 1930s, KSC was leasing over 2,850 hectares of agricultural land from the government; between 810 to 1,305 hectares of the leased land was "reclaimed" swamp lands located in the Mānā Plain. During renegotiation of the lease just prior to World War II, the Territory of Hawai'i considered the KSC lands their most valuable acreage in all Hawai'i. Towards the end of the era of sugarcane cultivation, KSC reported cultivating about 4,750 hectares of land for sugarcane and diversified agriculture in 1992 and around 3,140 hectares in the year 2000 (Bow Engineering [2]).

\section{RESULTS OF INVENTORY STUDY}

All sugarcane operations in the Kekaha region ceased in 2001. For a short time after the closure of operations, the former plantation infrastructure, including the ditches, was maintained by an informal agricultural coalition under an interim agreement with the State of Hawaii Department of Land and Natural Resources (DLNR). In 2004, the DLNR transferred management of 5,095 hectares of former KSC lands and infrastructure to the ADC, a state entity under the State of Hawai'i Department of Agriculture (DOA). In 2007, ADC gave KAA the responsibility for management, monitoring, and maintenance of the ditch system and the agriculture infrastructure, including control of the ditch diversions within the Waimea River watershed. Under this agreement, KAA is also responsible for maintaining the drainage system that prevents flooding of the low-lying lands surrounding the Pacific Missile Range Facility (PMRF) and inland portions of the town of Kekaha. ADC administers payments for the water used from the two ditch systems, which is based on a per acreage usage basis.

During the inventory survey, E2 found that the 45 kilometer long KEDIS is currently operated by KAA in a manner that focuses on production of electricity at the two hydroelectric plants (Mauka and Waiawa) on the ditch while still providing sufficient amounts of irrigation water to their members. As a result, most of the recent upgrades and repairs made by KAA to KEDIS were performed on the approximately 32 kilometers of ditches, tunnels, and flumes located between the upper intake at Waiahulu dam and the lower Waiawa hydroelectric plant. The greatest amount of leakage from KEDIS was observed in the roughly 12 kilometer section of ditch located between the Waiawa hydroelectric plant and the terminal reservoir at Polihale.

E2 conducted a series of flow measurements throughout both KODIS and KEDIS on December 2, 2014. Measurements of ditch flow began at the beginning of KODIS in the early morning and finished near the end of KEDIS in the early evening. The flow conditions within the watershed were typical for this time of year. The purpose of this single day of monitoring was to measure the flow of water through these two inter-related ditch systems and to quantify the degree of leakage throughout the system. Fig. 2 depicts the flow measurements, in units of millions of gallons per day (mgd), made during this synoptic study conducted on December 2, 2014. 


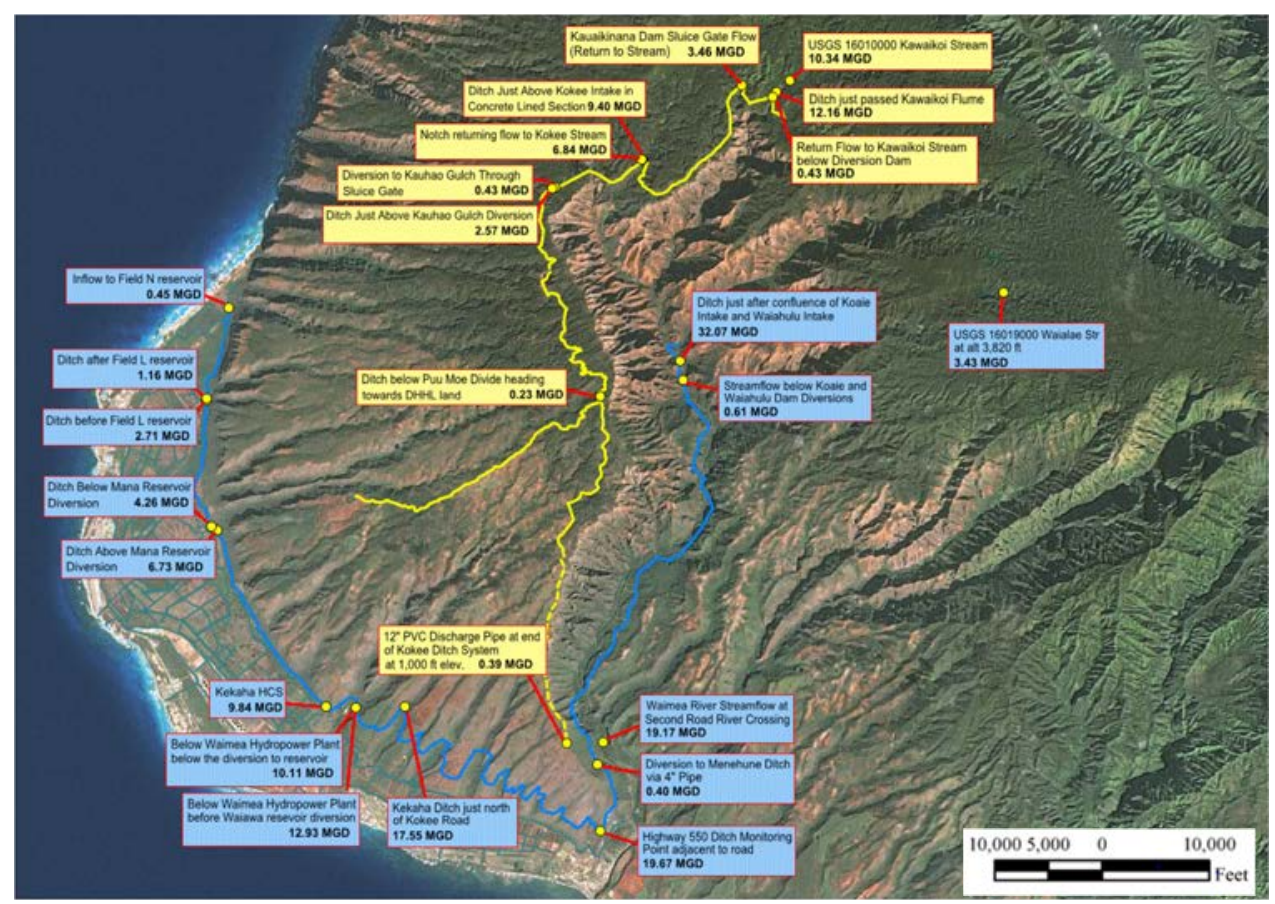

Figure 2: Synoptic stream and ditch flow measurements made on December 2, 2014.

The flow measurements made in the ditch and stream just below the Koaie and Waiahulu intakes on KEDIS is particularly relevant to the Earth Justice complaint. During the day of the survey, a total of 32.07 mgd of water was diverted into the ditch at these two intakes while only 0.61 mgd was present in the Waimea River below these diversion intakes. The complaint alleges that this ongoing diversion has been detrimental to the aquatic habitat within the stream, especially the abundance of native freshwater-amphidromous fishes such as 'o'opu (Lentipes concolor, Sicyopterous stimpsoni, and Awaous guamensis), 'Ōpae (Atya bisulcata), and hihiwai (Neritina granosa). The near-elimination of stream flow below these stream diversion structures is detrimental to these species that require access to the ocean to complete their amphidromous life cycle. Fig. 3 depicts the segments of streams and rivers within the Waimea River watershed that receive either increased or decreased streamflow due to diversions of natural streamflow to the two ditch systems, KODIS and KEDIS.

E2 installed pressure transducers within KODIS and KEDIS between June 22, 2015 and June 10, 2016 to continuously monitor the flow of water within these two ditches at tenminute intervals. The mean and median ditch flows determined using the continuous flow records during this period were similar to the monthly average values reported for both ditch systems by KAA to the Commission. The average measured velocity of water within these two ditch systems was measured to vary between 2 to 3 kilometers per hour, under normal flow conditions.

The black pipe siphon, which conveys the ditch water in KEDIS from the east side of Waimea River to the west side of the river, was replaced from August 2015 to October 2015 during the monitoring period. The redesign of the black pipe siphon involved reducing the 


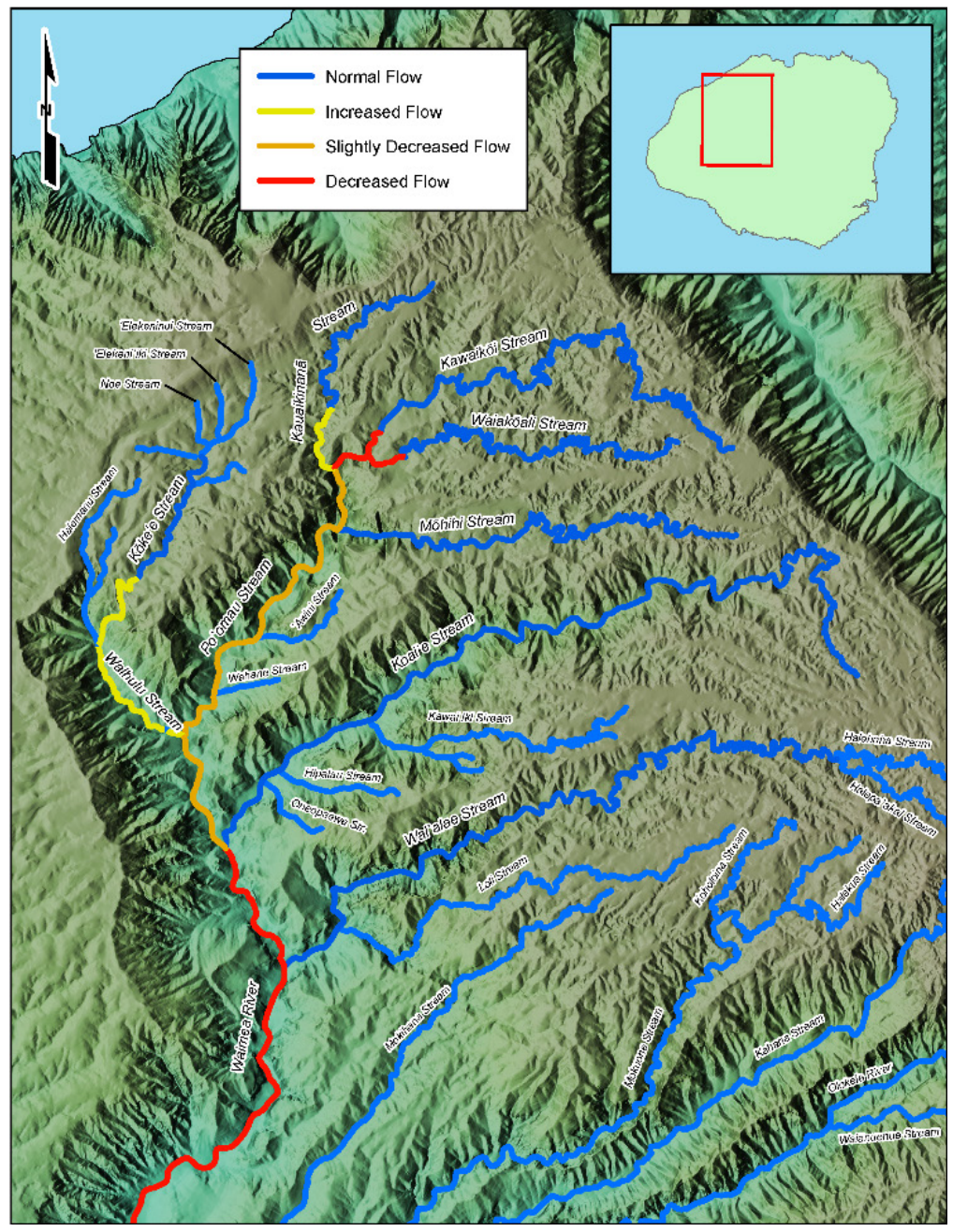

Figure 3: Stream segments receiving normal, increased, or decreased streamflow due to diversion of water into KODIS and KEDIS.

original transmission capacity of the siphon from 50 mgd to 23 mgd by installing roughly 300 meter of 81-centimeter diameter HDPE pipe within the original steel riveted section of pipe. A section of 48 centimeter inner diameter HDPE was slip lined in the section of the siphon that ran under the river. Cavitation issues related to the reconfigured siphon pipe further reduced the flow of water within the western portion of KEDIS after the siphon was brought back on-line. The narrowing of the pipe size within the siphon led to a significant decrease in monitored median ditch flow at the Hukipo Flume on KODIS during this study. Fig. 4 shows the variation in volume of ditch flow over a year of the study, including the time when the ditch was shut off during replacement of the black pipe siphon between August and October 2015. The narrowing of the pipe size within the siphon led to a decrease in monitored median ditch flow at the Hukipo Flume from 20.37 mgd between June 22, 2015 


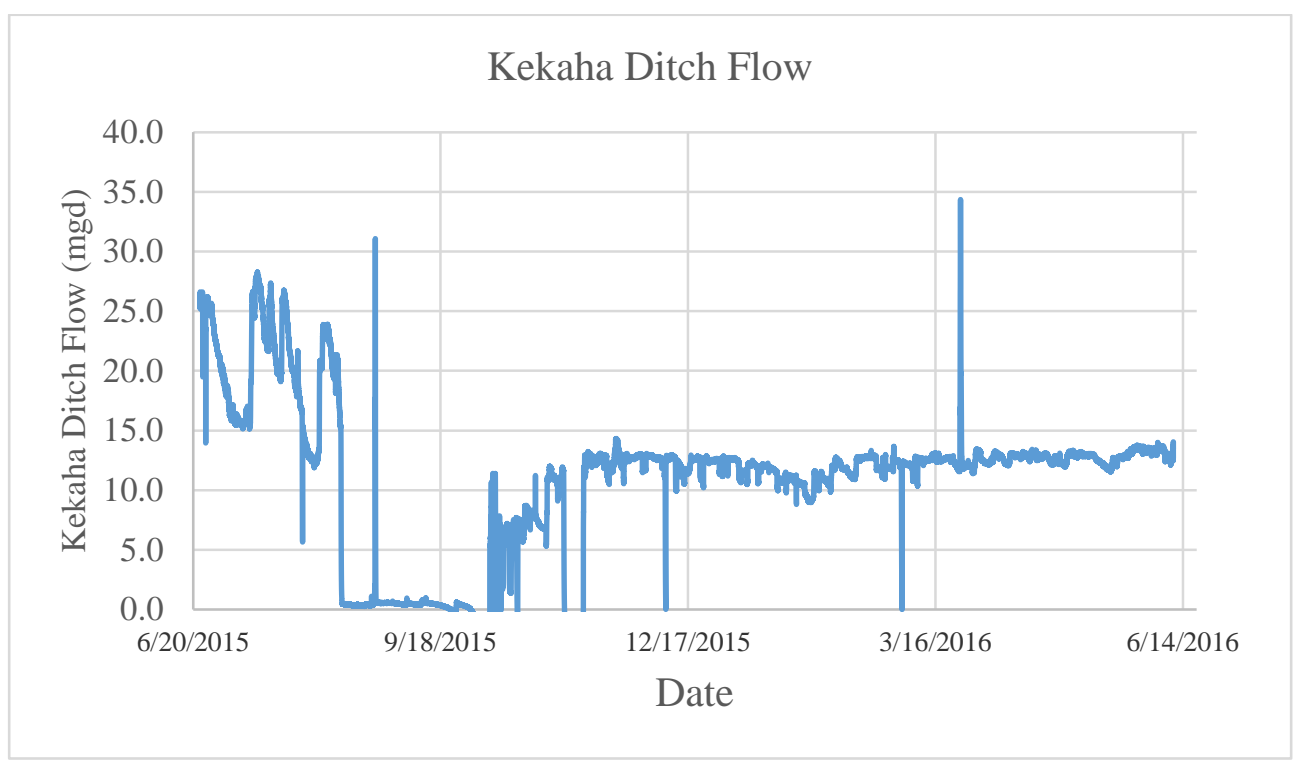

Figure 4: Continuous flow monitoring of Kekaha Ditch at Hukipo Flume.

and August 12, 2015 (pre-siphon modification) to 12.51 mgd from November 9, 2015 to June 10, 2016 (post-siphon modification) based on the continuous flow measurements made during this study. The sharp spikes in the continuous record observed while the ditch was shut down (8/25/15) and after replacement of the black pipe siphon (3/25/16) reflect the volume of stormwater runoff entering the roughly 4.0-kilometer section of ditch before the Hukipo Flume during heavy rainfall events (Fig. 4).

The flow in KODIS exiting the Waimea River watershed has significantly decreased since July 2013 when the flow of water entering Pu'u Lua Reservoir from the ditch was controlled to prevent the water level from rising above a level of 18 meter within this 262 million gallon capacity (when full) reservoir. As a result of the current storage limitations within Pu'u Lua Reservoir, the flow of water in the lower parts of KODIS is currently regulated by dumping the majority of water that is diverted from Waikoali and Kawaikōi streams into Kaua'ikiananā and Kōke'e Streams, thus retaining much of the diverted water in the upper portion of KODIS within the Waimea River watershed.

\section{DISCUSSION}

The median flow of water currently exiting the Waimea Valley watershed via KEDIS and KODIS (about $14.4 \mathrm{mgd}$ ) is significantly lower than historic median flows measured during the plantation era (about 48.5 mgd, 1908-1968) and the post-plantation period under KAA management (32.9 mgd, January 2010 to June 2013). As described above, the major causes of the observed reduction in water exiting the watershed via KEDIS and KODIS are: 1) the reduction of water levels within Pu'u Lua Reservoir to 18 meter or less in June 2013; and 2) the reduction of the interior diameter of the black pipe siphon in the summer of 2015. During the post-plantation era, the ditch operators have returned greater amounts of water (compared to the plantation era) from KEDIS to the Waimea River at two diversions located just below the Mauka hydroelectric plant and seldom captured additional streamflow at the Waimea diversion located just above the Mauka plant. 
The median monitored flow in KODIS just above Pu'u Lua Reservoir between June 2015 and December 2016 was 1.9 mgd, compared to historic median flows of 12.3 mgd measured by the United States Geological Survey (USGS) just upstream at the Kauhao diversion during the plantation era (1927-1997) and a median value of 8 mgd reported by KAA during the post-plantation era (January 2010 to June 2013), before water levels in Pu'u Lua Reservoir were regulated to not exceed 18 meter depth. The water that currently exits the Waimea River watershed via KODIS is currently used to: 1) oxygenate and provide evaporative replacement water at Pu'u Lua Reservoir; 2) provide roughly 0.25 mgd of water to Department of Hawaiian Homeland (DHHL) lands, which are currently used to raise cattle and cultivate taro; 3) provide water to a small upland farm located just west of the ditch (Wines of Kaua'i, LLC); and 4) provide back-up water to the Menehune Ditch during periods when the Kekaha ditch is closed (such as when the black pipe siphon was repaired during the summer and fall of 2015).

KEDIS and KODIS currently supply irrigation water for agricultural activities by KAA members (BASF, Pioneer, Syngenta, and Wines of Kaua‘i), for taro cultivation by farmers using the Menehune ditch system and DHHL lands, water for cattle grazing on DHHL lands, for firefighting purposes, and recreational uses (i.e., trout fishing at $\mathrm{Pu}$ ' $\mathrm{u}$ Lua Reservoir). The ditch water is used to irrigate corn, soy, sunflower, canola, rice, grapes, taro, and cover crops grown on roughly 1,710 hectares of land leased by KAA members as well as on additional lands farmed by non-KAA members. The estimated average daily water demand between 2010 and 2014 self-reported by the major KAA tenants averaged approximately 5.8 mgd during this five-year period.

The groundwater component of streamflow within the lower reaches of the Waimea River watershed was estimated using historic streamflow measurements made at monitoring stations during the most severe historic drought to occur on Kaua'i between April and November 1953. Based on the stream measurements made during this intense drought, it is estimated that approximately 20 mgd of groundwater enters Po'omau Stream, the upper section of the main Waimea River along with the lower sections of the main tributaries (Koaie and Wai'alae) to the Waimea River as base flow from daylighting of dike-impounded groundwater from the marginal dike zone of the Waimea Canyon Volcanics, along with additional contribution from seepage of groundwater from rocks associated with the Olokele Volcanics. This rate of groundwater input to the Waimea River is similar to estimates of flow contributions of dike-impounded aquifers entering the Waiahole ditch system on O'ahu (19 mgd), the Lower Hamakua ditch system on Hawai'i (19 mgd) and the Honokoha ditch system on West Maui (14 mgd) (Mink and Lau [3]).

Fig. 5 depicts an estimate of the future median flow within the Waimea River, tributary streams and irrigation ditches given the current operational state of the two ditch systems. It is estimated that the future median value of flow measured at this station will increase roughly four-fold from the historic average flow of 10.3 mgd measured during the plantation era to around 42.5 mgd.

Table 1 summarizes the findings obtained during this study related to the major allegations contained in the Earthjustice complaint against ADC and its land manager, KAA.

\section{AUXILLARY USES OF KODIS AND KEDIS}

KEDIS produces electrical power at two hydropower plants, Mauka and Waiawa, that is used to power pumps that irrigate the flat lying agricultural fields throughout the Mānā Plain as well as to power the large dewatering pumps at Kawai'ele, Nohili, and Kekaha which protect the PMRF and the town of Kekaha from flooding during periods of heavy rainfall. Based on data provided by KAA for the period of January 2010 through December 2014, the Mauka 
and Waiawa Hydropower Plants daily production rate was 432 and $328 \mathrm{~kW}$, respectively. This translates into a little more than 2.3 million dollars per year of generated electricity based upon rates charged by the Kaua'i Island Utility Cooperative to Large Power consumers during this period.

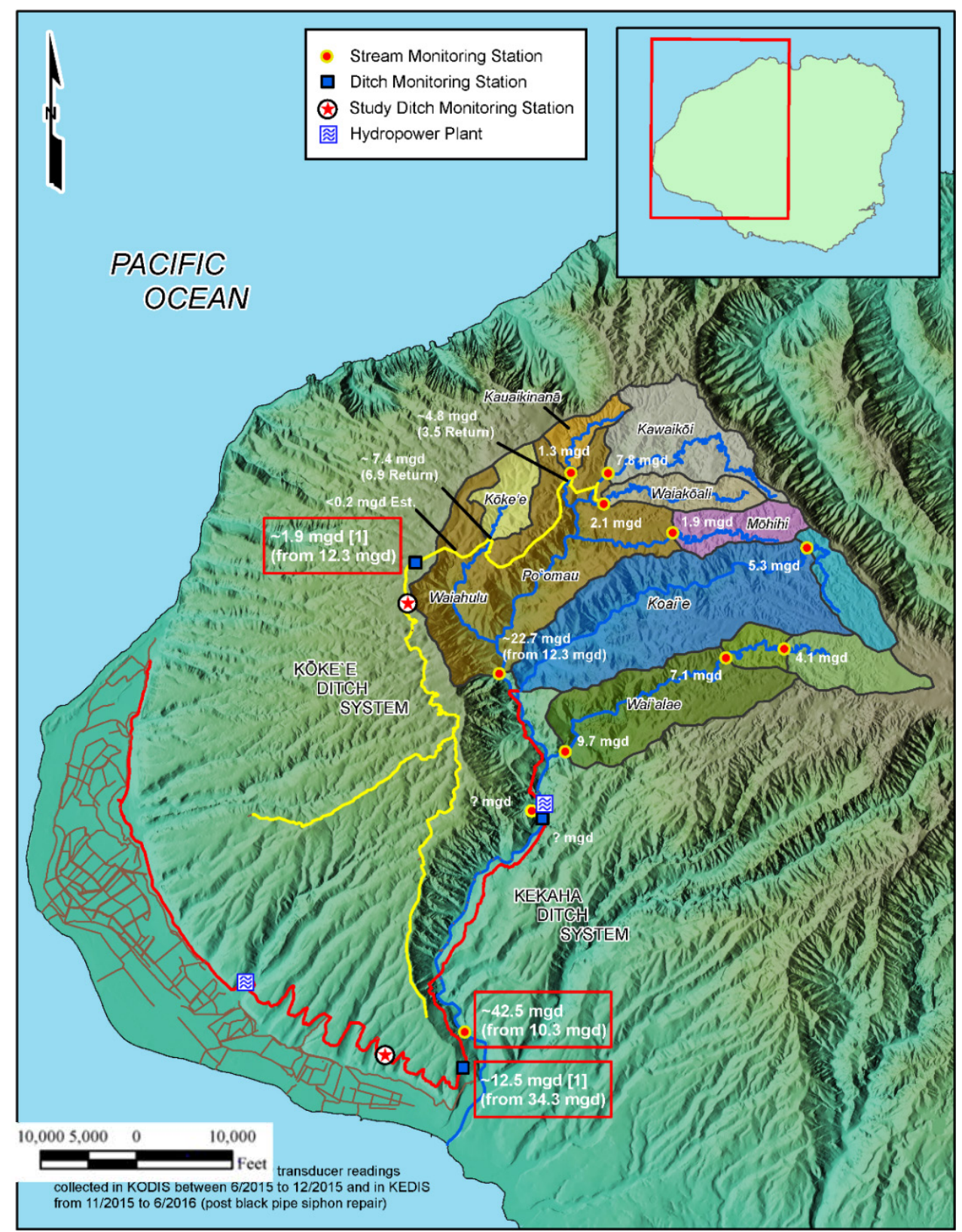

Figure 5: Future estimated stream/ditch Q (50) in Waimea Watershed. 
Table 1: Summary of findings related to Earthjustice allegations.

\begin{tabular}{|c|c|}
\hline Earthjustice allegations & Finding \\
\hline $\begin{array}{l}\text { In contrast to the sugarcane } \\
\text { plantation operations, the current } \\
\text { agricultural tenants under } \\
\text { ADC/KAA cultivate only a fraction } \\
\text { of Kekaha Sugar's former lands, in } \\
\text { far less land- and water-intensive } \\
\text { crops. the glaring discrepancy } \\
\text { between the ongoing diversions and } \\
\text { the radically reduced water demands } \\
\text { indicates that the diverted river flows } \\
\text { are not being put to maximum } \\
\text { reasonable-beneficial use, but rather } \\
\text { are being wasted, contrary to law. } \\
\text { causes an unknown amount of waste } \\
\text { Despite this dramatic decline in } \\
\text { cultivation and actual water demands } \\
\text { due to Kekaha Sugar's closure, } \\
\text { ADC/KAA continue to divert } \\
\text { Waimea River flows in amounts } \\
\text { comparable to the sugarcane } \\
\text { plantation. }\end{array}$ & $\begin{array}{l}\text { The current median flow of water diverted outside } \\
\text { the Waimea River watershed via KODIS is } 1.9 \\
\text { mgd, compared to historic median flows of } 12.28 \\
\text { mgd measured by the USGS just upstream at the } \\
\text { Kauhao diversion during the plantation era (1927- } \\
\text { 1997) and a median value of } 8 \text { mgd during the } \\
\text { post-plantation era under KAA management } \\
\text { (January 2010-June 2013) before water levels in } \\
\text { Pu'u Lua Reservoir were regulated to not exceed } \\
60 \text { feet depth. The current median flow of water } \\
\text { diverted outside the Waimea River watershed via } \\
\text { KEDIS is } 12.51 \text { mgd compared to historic median } \\
\text { flows of } 34.25 \text { mgd measured at USGS Station } \\
16027000 \text { during the plantation era (1908 to } 1934 \text { ). } \\
\text { KAA members currently lease a total of } 4,226.35 \\
\text { acres of land and report having used an average of } \\
5.81 \text { mgd of water between } 2010 \text { and 2014. The } \\
\text { ditch infrastructure is generally well maintained, } \\
\text { with the exception of the section of KODIS past } \\
\text { the Waiawa hydroelectric plant. }\end{array}$ \\
\hline $\begin{array}{l}\text { Native Hawaiians are limited in their } \\
\text { rights to gather stream life such as } \\
\text { 'o'opu, 'Ōpae, and hihiwai. As } \\
\text { explained above, the Waimea River } \\
\text { system was legendary for the } \\
\text { abundance of its native stream life, } \\
\text { including 'o'opu. These resources, } \\
\text { however, have markedly declined } \\
\text { with the continued long-term } \\
\text { diversion of the river and cannot } \\
\text { support the traditionally practiced } \\
\text { and currently desired levels of } \\
\text { gathering. }\end{array}$ & $\begin{array}{l}\text { A biological assessment of portions of the Waimea } \\
\text { river and tributary streams that are diverted and } \\
\text { receive either slightly decreased or significantly } \\
\text { decreased flow over natural conditions is required } \\
\text { to answer this assertion. Fig. } 3 \text { of this paper } \\
\text { identifies the general sections of the Waimea River } \\
\text { and tributary streams that currently have decreased } \\
\text { flow over natural conditions. }\end{array}$ \\
\hline
\end{tabular}

KEDIS and KODIS provide fire protection for the lands that surround the two ditch systems. At higher elevations, the water stored in Pu'u Lua Reservoir on KODIS can be accessed by helicopters for fighting wildland fires. At lower elevations, the water stored in the various irrigation reservoirs on KEDIS located along the Mānā Plain as well as a rectangular shaped dip pool located adjacent to KEDIS just to the east of the Hukipo Flume can be accessed by helicopters for fire-fighting purposes.

The section of KEDIS that runs above the Mānā Plain also provides a level of flood protection to the flat lying areas below, including portions of Waimea and Kekaha town. The 
pressure transducer placed in the Hukipo Flume measured transient spikes in water level within the ditch system during a large storm event that hit the area between March 24 and 25, 2016. It is estimated that the roughly 4.0 kilometer section of KEDIS between the flume and Highway 550 captured roughly 5.2 million gallons of storm water runoff during this rainfall event (see Fig. 4). An additional 10 million gallons of storm water runoff was also likely intercepted by the remaining, 8 kilometer elevated section of KEDIS between the Hukipo Flume and the penstock above the Waiawa Hydropower plant.

The largest reservoir on KODIS, Pu'u Lua Reservoir, is stocked with rainbow trout by DLNR. The Kōke'e Public Fishing Area is typically open to the public during daylight hours from June to September. In 2016, the trout fishing season began on June 18 and ran until September 30. The daily bag limit is 12 trout per person. In 2015, a total of 3,837 anglers caught 28,831 trout from the reservoir. The largest fish caught at Pu'u Lua Reservoir in 2015 measured 47 centimeters in length and weighed 1.05 kilograms (DLNR 2016). Fishing is only allowed from the banks of the reservoir. Trout fishing is expected to be good this year as more than 30,000 young trout were stocked in the reservoir late last year.

The segment of KODIS that runs from the Pu'u Moe Divide to Pu' $u$ 'Ōpae passes through a 6,095 hectare section of land administered by the Department of Hawaiian Homelands (DHHL) that is currently used for hunting and a few pastoral homestead lots occupied by DHHL beneficiaries. DHHL has claims to use of the water conveyed within KODIS that runs through this parcel. DHHL has previously proposed designating the area surrounding $\mathrm{Pu} u$ 'Ōpae as a Pu'uhonua, or retreat and refuge area.

In recent years, a number of proposals have been advanced for using the water stored in the existing reservoirs on KODIS to produce electricity using various forms of pumped hydropower storage technology. Projects that utilize $\mathrm{Pu}^{\prime} \mathrm{u}$ Lua and $\mathrm{Pu}^{\prime} \mathrm{u}$ 'Ōpae reservoirs as the upper storage ponds for a pumped storage system are currently under consideration. Both projects would require rehabilitation of the existing earthen reservoirs to meet current dam safety standards. Water stored in these reservoirs would be connected to a lower storage pond located on the Mānā Plain by either an 8.0 or 4.0 kilometer long buried steel pipeline. A powerhouse and pumping station would be located beside either a new or rehabilitated lower, approximately 30 million gallon storage reservoir on the Mānā Plain.

Pumped hydropower could help the Kaua 'i Island Utility Cooperative (KIUC) to "store" excess energy produced by the island's rapidly expanding utility-scale photovoltaic array systems. The solar power would be used to pump water uphill from the lower to the upper reservoir during the day. The same water would then be reused by releasing it down the steel pipeline to turn a turbine, which would create electricity at night. An environmental advantage of this type of system is that it requires little additional diversion of water into the upper reservoir since the water is cycled between the upper and lower reservoir via the steel pipeline.

It is estimated that these projects would cost between $\$ 55$ to $\$ 65$ million dollars to construct and would be capable of generating about 25 megawatts of electricity. By comparison, KIUC currently has a 78 megawatt peak power generating capacity. The cost of electricity generated by the hydropower storage system would initially be about 35 percent less than the cost of electricity produced from oil and once the pump storage facility is paid off, would fall to only a few pennies per megawatt-hour, according to Jim Kelly, the communications manager for KIUC.

\section{RECOMMENDATIONS BASED ON STUDY FINDINGS}

The recent regulation of water levels within the Pu'u Lua Reservoir since July 2013 and the reduction in pipe diameter of the Black Pipe siphon during the summer of 2015 has led to a 
significant reduction of the median volume of water exiting the Waimea Valley watershed via KEDIS and KODIS (about 14.4 mgd) compared to median volumes diverted from the watershed during the plantation era (about $48.5 \mathrm{mgd}$ ).

The median streamflow at the USGS Waimea River stream monitoring station (Station Number 1603100), which is located approximately 2,300 meter upstream of the confluence between the Waimea and Olokele Rivers, is estimated to have increased from the Plantation era (1910-1997) value of 10.3 mgd to a current median value of around 42.5 mgd due to these recent operational changes in the volume of water diverted into KODIS and KEDIS (Fig. 5). The USGS recently restored operation of the Waimea River stream monitoring station, which had been discontinued in 1997. The future stream monitoring data collected by the USGS from this restored gaging station will be useful in evaluating the projected fourfold increase in median river flow in the lower half of the Waimea River due to recent changes in operation of KEDIS and KODIS.

A biological survey of the sections of the stream system that are subjected to near complete diversion of surface water was recommended to evaluate the impact to the river ecosystem in these areas (Fig. 3). In particular, a biologic assessment is recommended of the roughly 2,750 and 2,150 foot long sections of streambed between the diversion structures on the Waikoali and Kawaikōi Streams and the first large waterfall that conveys water in these streams to Po'omau Canyon. In addition, a biologic assessment of the roughly 8,000 foot long section of the Waimea River, located between the diversions on the Koaie and Waiahulu and the confluence of the Waimea River and Wai'alae Stream, is recommended.

\section{REFERENCES}

[1] Parham, J.E., Higashi, G.R., Lapp, E.K., Kuamo’o, D.G.K., Nishimoto, R.T., Hau, S., Fitzsimons, J.M., Polhemus, D.A. \& Devick, W.S., Atlas of Hawaiian Watersheds \& Their Aquatic Resources, Island of Kaua‘i, Bishop Museum \& Division of Aquatic Resources. 614 pp., 2008.

[2] Bow Engineering and Development, Inc. 2000. Kekaha Sugar Infrastructure Study, Kekaha, Kaua'i. Hawai‘i. Report dated April 17, 2000.

[3] Mink J.F. \& Lau, L.S., Hydrology of the Hawaiian Islands. University of Hawai'i Press, 274 pp., 2006. 